\title{
STUDIES ON FOLIICOLOUS FUNGI - IV A NEW SPECIES OF ASTERINA AND KEY TO OTHER SPECIES ON DIPTEROCARPACEAE
}

\author{
V.B. Hosagoudar \\ Microbiology Division, Tropical Botanic Garden and Research Institute, Palode, Thiruvananthapuram, Kerala 695562, India.
}

\begin{abstract}
Asterina hopeae is the new species described and illustrated on Hopea ponga. Key is provided to other

Asterina species known on the members of Dipterocarpaceae
\end{abstract}

Keywords

Foliicolous fungi, Asterina hopeae, new species, Dipterocarpaceae

\begin{abstract}
Abbreviations
TBGT - Tropical Botanic Garden, Thiruvananthapuram
\end{abstract}

Asterina hopeae V.B. Hosagoudar et M. Kamarudeen, sp. nov. (Fig. 1)

\begin{abstract}
Material examined
Holotype: 10.i.2001, M. Kamarudeen HCIO, on leaves of Hopea ponga (Dennst.) Mabberley (Dipterocarpaceae), in the campus of Tropical Botanic Garden and Research Institute, Palode, Thiruvananthapuram, Kerala, India.
\end{abstract}

Isotype: $T B G T$

Distribution

India: Tropical Botanic Garden and Research Institute, Palode, Thiruvananthapuram, Kerala.

\section{Diagnostic features}

Coloniae epiphyllae, subdensae, ad 3mm diam., confluentes. Hyphae rectae vel subrectaae, alternate vel irregulariter

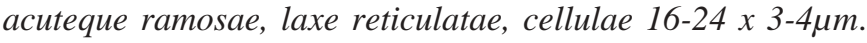
Appressoria altemata vel unilateralia, plerumque conoidea, clavata, ovata, attenuata et late rotundata, ad apicem, integra, 6-10 $\times 4-7 \mu \mathrm{m}$. Thyriothecia dispersa, raro connata, orbicularia, ad 176um diam., stellato dehiscentes ad centro, margine fimbriatae, hyphae fringiorae longae, flexuosae; asci numerosi, globosi vel ovati, octospori, ad $45 \mu \mathrm{m}$ diam.; ascosporae oblongae, conglobatae, brunneae, uniseptatae, constrictae, 24-28 x 11-134m, parietus glabrus, tuberculatus ad maturitatus.

Colonies epiphyllous, subdense, up to $3 \mathrm{~mm}$ in diameter, confluent. Hyphae straight to substraight, branching alternate to irregular at acute angles, loosely reticulate, cells 16-24 x 3$4 \mu \mathrm{m}$. Appressoria alternate to unilateral, mostly conoid, clavate, often ovate, attenuated and broadly rounded at the apex, entire, 6-10 x 4-7 $\mu \mathrm{m}$. Thyriothecia scattered, rarely connate, orbicular, up to $176 \mu \mathrm{m}$ in diameter, stellately dehisced at the centre, margin fimbriate, fringed hyphae long, flexuous; asci many, globose to ovate, actosporous, up to $45 \mu \mathrm{m}$ constricted at the septum, 24-28 $\mathrm{x} 11-13 \mu \mathrm{m}$, wall smooth, tubercled in matured spores.

So far six species of the genus Asterina are known on the host genera Anisoptera, parashorea and Shorea of the family Dipterocarpaceae (Hosagoudar \& Abraham, 2001). Of these, Asterina shoreana Sacc. does not represent external mycelium, while, A. camarinensis Sydow \& Sydow and A. anisopterae Sydow \& Sydow have nodulose appressoria in the mycelium (Saccardo, 1924). Hence, these are the doubtful species ofs the genus Asterina. Asterina hopeae differs from A. anisoptericola Hansf. in having unicellular appressoria and from A. rizalensis Hansf. in absence of $90 \%$ opposite appressoria (Hansford, 1949). 


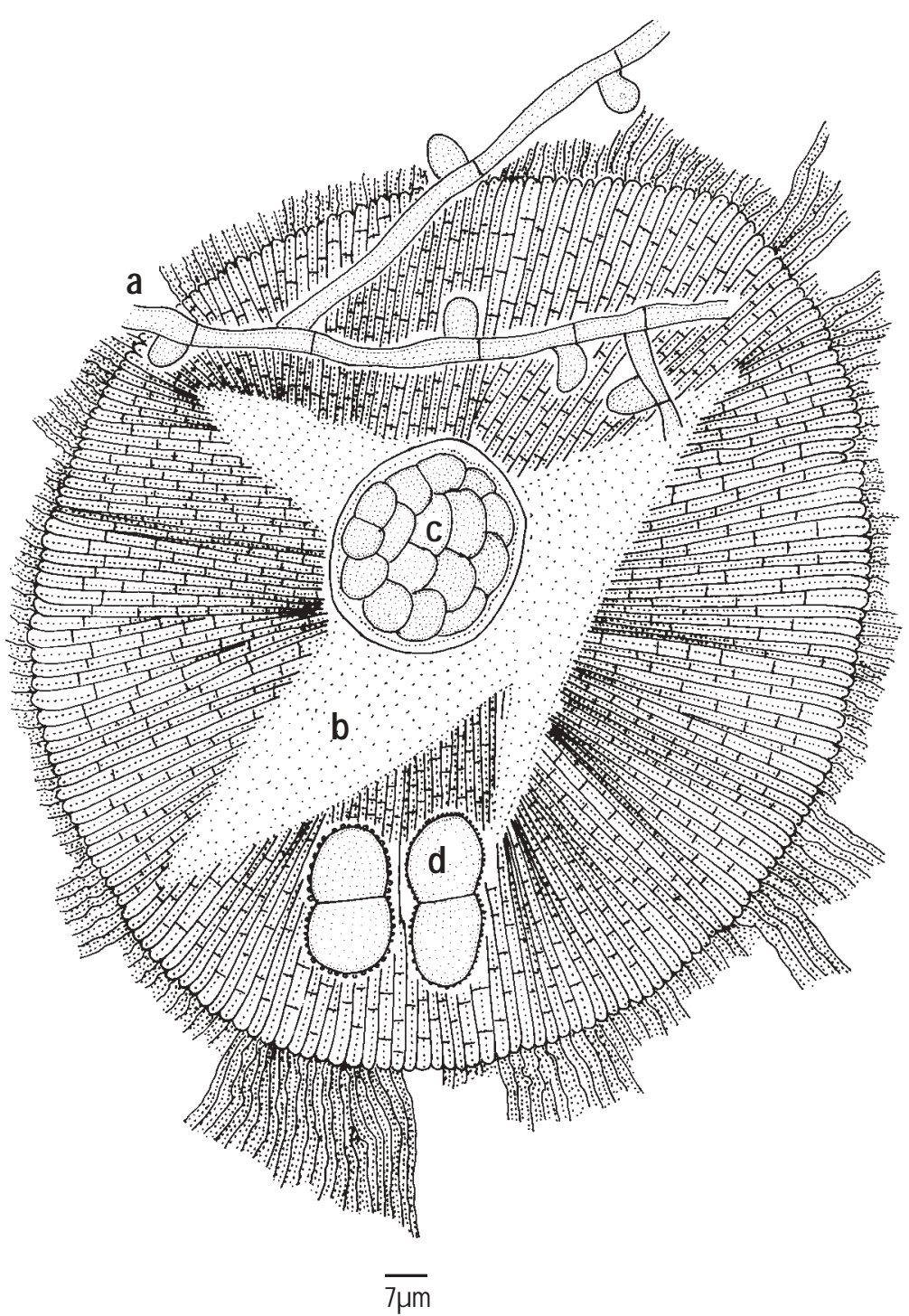

Figure 1. Asterina hopeae sp. nov.

a - Appressoriate mycelium; $b$ - Staellately dehisced thyriothecium; c - Ascus; $d$ - Ascospores
A. plurispora Ryan, known from India, differs from the present new species in having crookshaped appressoria.

\section{Acknowledgement}

Author thanks Dr. G. Sreekandan Nair, Director, TBGRI, Palode for the facilities and Mr. C.K. Biju for his assistance in preparing the manuscript.

\section{References}

Hansford, C.G. (1949). Tropical fungi - III. New species and revisions. Proceeding of the Linnean Society, London 160: 116-153.

Hosagoudar, V.B. and T.K. Abraham (2000). A list of Asterina Lev. species based on the literature. Journal of Economic and Taxonomic Botany 24: 557-587.

Ryan, W. (1927). Asterina spp. from India. Memoirs of the Department of Agriculture, India 15: 103-105

Saccardo, P.A. (1924). Sylloge fungorum 24: 450451.

\section{Key to Asterina species known on Dipterocarpaceae}

1. Appressoria bicellular anisoptericola

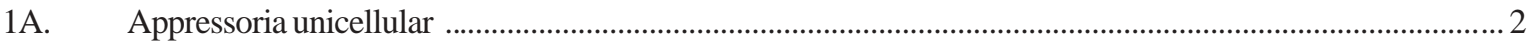

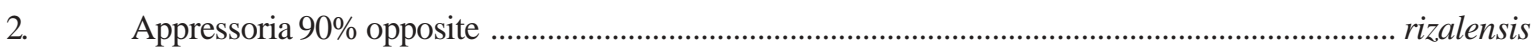

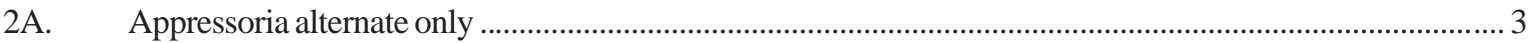

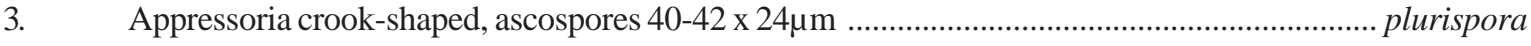

3A. Appressoria conoid to ovate, ascospores $24-28$ x $11-13 \mu \mathrm{m}$.......................................... hopeae sp. nov. 